\title{
ASSESSMENT OF TECHNICAL CONDITION OF AN ACCUMULATOR COMMON RAIL INJECTOR BY TEMPERATURE OF ITS UNITS
}

\author{
Ildar Gabitov ${ }^{1, *}$, Andrei Negovora ${ }^{1}$, Azamat Valiev', Vladimir Ilin², Danila Plotnikov', Mahmut Razyapov ${ }^{3}$ \\ ${ }^{1}$ Department of Automobiles and Machine - Tractor Complexes, Federal State Budgetary Educational Establishment of \\ Higher Education Bashkir State Agrarian University, Ufa, Russian Federation \\ ${ }^{2}$ Department of Computer Science and Information Technology, Federal State Budgetary Educational Establishment of \\ Higher Education Bashkir State Agrarian University, Ufa, Russian Federation \\ ${ }^{3}$ Department of Infectious Diseases, Zoohygiene and Veterinary Sanitary Inspection, Federal State Budgetary Educational \\ Establishment of Higher Education Bashkir State Agrarian University, Ufa, Russian Federation
}

*E-mail of corresponding author: gabitov.ildar@yahoo.com

\section{Resume}

This paper presents a method for the vehicle speed estimation with a Fuzzy Logic based algorithm. The algorithm acquires the measurements of the yaw rate, steering angle, wheel velocities and exploits a set of five Fuzzy Logics dedicated to different driving conditions. The technique estimates the speed exploiting a weighted average of the contributions provided by the longitudinal acceleration and the credibility assigned by the Fuzzy Logics to the measurements of the wheels' speed. The method is experimentally evaluated on an all-wheel drive electric racing vehicle and is valid for the front and rear wheel drive configurations. The experimental validation is performed by comparing the obtained estimation with the result of computing the speed as the average of the linear velocity of the four wheels. A comparison to the integral of the vehicle acceleration over time is reported.

Available online: https://doi.org/10.26552/com.C.2021.2.B130-B138

\section{Article info}

Received 2 April 2020

Accepted 19 August 2020

Online 4 February 2021

\section{Keywords:}

automotive engineering, vehicle dynamics, fuzzy logic electric vehicles, speed estimation

\section{Introduction}

Almost all the modern diesel fuel equipment (FE) is provided with microprocessor controls and is characterized by high injection pressures (up to 220-250 $\mathrm{MPa}$ ), due to high requirements for the level of energy, economic and primarily environmental indicators of internal combustion engines [1-6]. The most promising from fulfilling all the strict requirements for emission of harmful substances, noise level and fuel economy are accumulator fuel supply systems of the Common Rail (CR) type [7-10].

The design documentation establishes the criteria for the limit state of diesel fuel supply systems, by the design documentation of its manufacturers and their values are measured during diagnosis, which is aimed at identifying the correspondence of the actual parameters to the prelaunch ones. The comparative analysis of more than 500 major electronic injectors malfunctions of the CR type was carried out in the service companies for technical maintenance of diesel FE Bashdiesel LLC (Russia, Ufa) and Carwood Motor Units Ltd. (Great Britain, Birmingham). They showed that the main wear of units of this type in Russia is of the shut-off valve (control unit). In the UK they are of the atomizer (loss of hydro-density along the leading surface of the atomizing unit) (Figure 1). It is explained, first of all, by the worse operating conditions and the quality of diesel fuel (the friction medium is low molecular weight liquid (fuel) [1,9]. It is currently impossible to determine the malfunction of a particular unit by the in situ way even by measuring fuel consumption for control [1, 7, 11], because its increase may indicate a malfunction of the sprayer and / or control valve. It is necessary to disassemble the injector from the engine and conduct the non-motor tests to assess the compliance of operational parameters with the pre-launch ones for specific modes (VL - maximum load (maximum torque), EM - average load, LL - idle speed, VE preliminary injection) specified in the test plan [9, 12-13]. The technical condition of a particular unit can be assessed, in the most cases, only after passing through the entire test cycle with the subsequent replacement/adjustment of "faulty" elements. The complexity of such a work is 15-30 $\mathrm{min} /$ person for each injector, since replacing one of its units does not guarantee the serviceability of another (re-conducting the entire test cycle is required) [1, 7].

The purpose of this research is to determine the operational parameters of the CR-injectors, allowing them to evaluate the technical state of the units in an in situ way. The research objective is to define a dependency between 

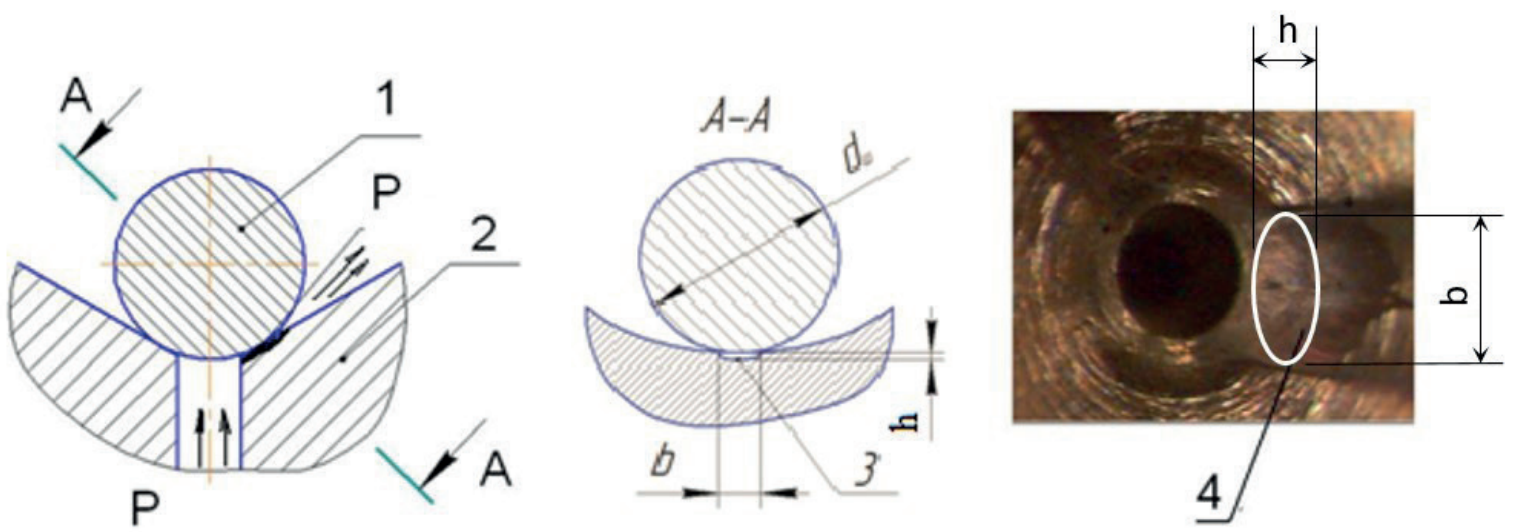

Figure 1 Design of the gap (darkened) in the pair "valve seat - ball" $d_{b}$ - is the diameter of the ball; $h$ - is the depth of the wear groove; $b$ is the width of the wear groove; 1 - valve ball; 2 - valve seat; 3 - profile of the wear groove (clearance); 4 - a view of a valve seat wear groove (top view without a ball)

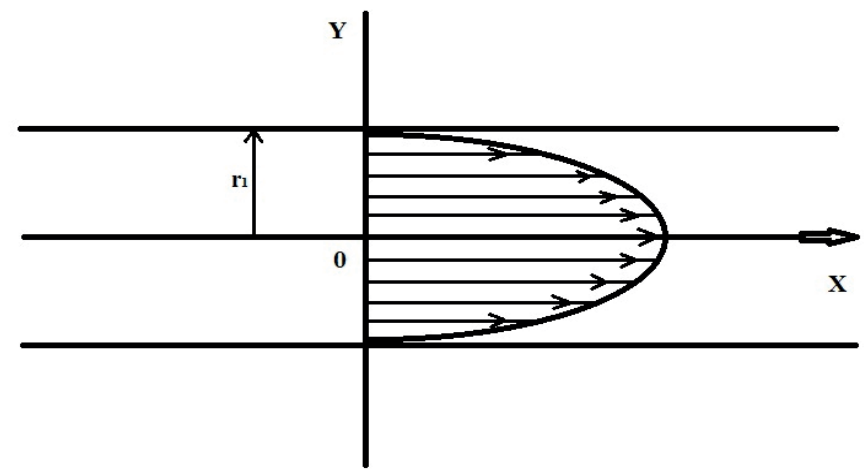

Figure 2 Distribution of flow rates of a viscous fluid in a circular pipeline with a steady flow

the technical state of $\mathrm{CR}$ units and the temperature. There are various methods (vibroacoustic, spectrographic, magnetoelectric, thermal, hydraulic, gas-analytical, kinematic) of in situ and disassembled diagnostics are used to assess the technical condition of CR type FE. In this case, the thermal method was preferable.

\section{Materials and methods}

\subsection{Equipment}

The non-motor tests were carried out in accordance with the State Standard 105178 and 10579, ISO 4008, ISO 8984 [14-16] using a specialized test bench for adjusting and testing diesel FE EPS 708 with Bosch electronic measuring system KMA 802 [12-13]. The diesel FE tests were carried out according to the test plans in its software control system, with a CRI retrofit kit for testing Common Rail injectors of the corresponding makes and models. As a test fluid, Shell Calibration Fluid S.9365 process fluid was used, which meets the requirements of ISO 4113 [7, 12].

The test bench has the water cooling and an electric heater built into the fuel tank, which allows to set and maintain the required temperature of the process fluid at the injector inlet. In the case of using the KMA 802 measuring system, the measurement of the cyclic fuel supply is much faster than in the "beaker" system, i.e. in the course of one measurement, the temperature of the fuel inside the tested $\mathrm{FE}$ can be considered constant. In addition, the use of electronic KMA 802 allows to exclude errors in the deposition of fuel / drain and the impact of the subjective human factor on the measuring process [9].

For the experiments, a Testo-875 thermal imager was used, the calibration of which (determination of the emissivity) for taking thermograms was carried out using an electronic thermometer W1209. The radiation coefficient for the CR-injector of the Altai Precision Devices Factory (APDF) A- 04-011-00-00-03 was 0.35.

\subsection{Modeling}

For more than $95 \%$ of time during the operation, the electronic injector shut-off valve is in the closed state and the size of the section of the valve clearances during wear is no more than $5 \%$ of its bore in the open state $[1,9]$. Fuel leaks in the closed valve position occur only through the clearance in the valve seat mating (Figure 1).

According to studies [1], the surface wear section of a technically faulty valve is half the ellipse (item 4 in Figure 1) and the maximum wear occurs on the valve seat [2]. 


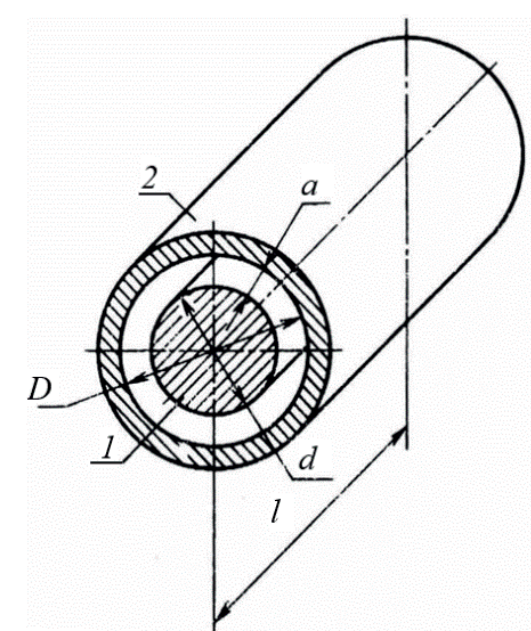

Figure 3 Design scheme of the annular gap

The main movement of the fluid flow in this case occurs along the wear groove (Figure 2), representing the outflow of fluid through the nozzle. For a steady flow (constant pressure at the inlet of the injector) it can be expressed by the transformation of the Navier-Stokes equation at $\mathrm{r}=\mathrm{r}_{1} ; \quad \mathrm{u}_{\mathrm{x}}=0$ and $\mathrm{r}=0\left(\frac{d u_{x}}{d r}=0\right)$ (Equations (1)-(4)), where $\mu$ is the flow coefficient (dynamic viscosity); $u$ is the fuel flow rate through the gap; $V$ is the fluid flow rate; $l$ is the hydraulic diameter of the gap (gap length); $\Delta P$ - differential pressure in the gap; $Q$ is the fluid flow rate; $F$ is the wear cross-sectional area. Thus, with a steady flow characteristics of the CR systems, the maximum fluid velocity will be two times higher than the average flow velocity [17-18].

$\frac{d P}{d x}=\mu\left(\frac{d^{2} u_{x}}{d r^{2}}+\frac{d^{2} u_{x}}{r d_{r}}\right)=\mu \frac{1}{r} \frac{d}{d r}\left(r \frac{\partial u_{x}}{\partial x}\right)$

$u_{\max }=\frac{\Delta P}{4 \mu l} r_{1}^{2}$

$V_{c r}=\frac{Q}{F}=\frac{1}{\pi r_{1}^{2}} \int_{0}^{r_{1}} \frac{\Delta P}{4 \mu l}\left(r_{1}^{2}-r^{2}\right) 2 \pi r d r=\frac{\Delta P}{8 \mu l} r_{1}^{2}$,

$V_{c p}=\frac{1}{2} u_{\max }$.

The fluid flow through a precision pair of "atomizer guide - its body" (with their fluid density not meeting the technical requirements) can be represented by Equation (5). Thad defines fluid movement through an annular gap (where the height $a$ is much smaller than the diameter $d$, and the gap can be considered flat, where height $a_{0}=$ (D d)/2, width $b=\pi d$ ) (Figure 3).

$Q_{\text {a.g. }}=\frac{\pi d a^{3}}{12 \mu l} \Delta p$

If the annular gap is not concentric, which is typical when the nozzle is worn along the needle guide part, then the height of the gap is:

$a=\frac{D}{2}-\frac{d}{2}+e \cos \varphi=a_{0}(1+\varepsilon \cdot \cos \varphi)$, where:

$e$ is the eccentricity;

$\varphi$ is the angle determined by the eccentricity over a length $l$, $\varepsilon=e / a_{0}$ - relative eccentricity.

Upon the contact of the plunger 1 with the sleeve 2 (Figure 1) (relative eccentricity $e=1$ ), a stream will flow through the resulting non-concentric annular gap, 2.5 times more than the flow in the concentric gap:

$Q_{\text {n.a.g. }}=Q_{\text {a.g. }}\left(1+\frac{3}{2} \varepsilon^{2}\right)=2.5 Q_{\text {a.g. }}$

Thus, an increase in the liquid flow rates of the worn-out precision pairs of control units and spraying of the CR injector ( 2 and 2.5 times, respectively) can affect the temperature regime of their operation due to the hydrodynamic friction of the fuel in its channels.

\subsection{Data analysis}

The experimental technique was as follows: several CR-injectors of the APDF A-04-011-00-00-00-03 of the YaMZ6565 / -6585 EURO-4 diesel engine, with previously known malfunctions of the corresponding units, as well as injectors in the entirely correct technical condition, were selected. Then, they were installed alternately on the EPS 708 stand with KMA 802 and tests were carried out with an absolute ramp pressure (for $160 \mathrm{MPa}$ ) indicated in the test plan. During the tests, the temperatures of the control units and injector atomization, cyclic supply and fuel consumption for control, were measured (Figures 4-7). The temperature at the inlet of the injector inlet was maintained in the range of $40 \pm 1{ }^{\circ} \mathrm{C}$, the duration of the "warm-up" of the injector before testing was 1000 cycles (1 minute at an injection frequency of 1000 injections / min). As the most informative mode affecting the temperature of the CR-injector units, the maximum torque mode was selected at which the pressure at the injector inlet is maximum and, as a result, the hydrodynamic friction and heating of the units were the greatest. 


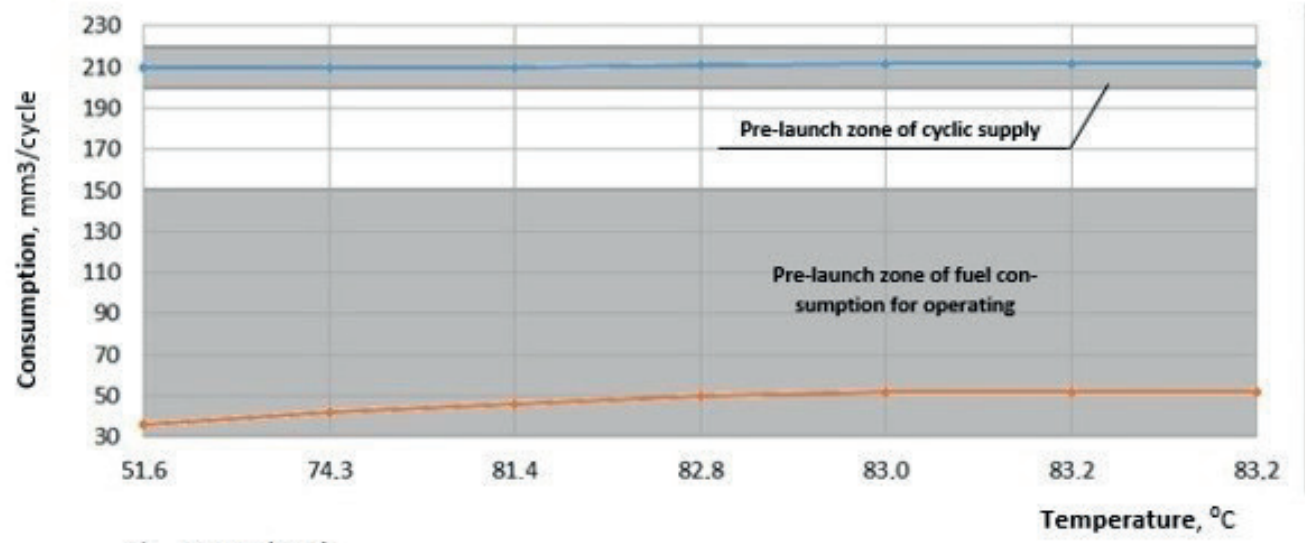

a) control unit
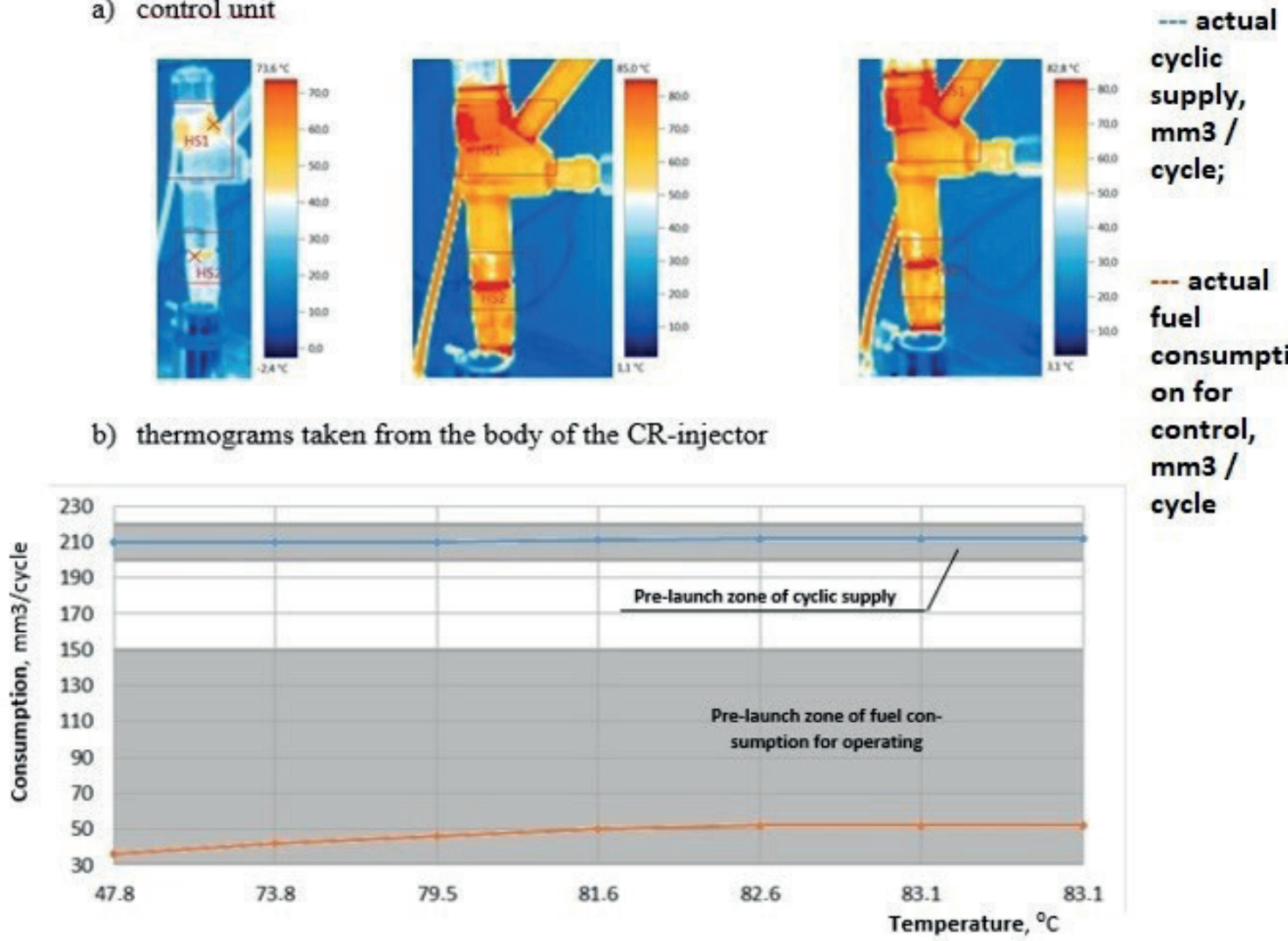

cycle

\section{c) atomization unit}

Figure 4 Dependences of the cyclic supply and fuel consumption for control on temperature of the housing of injection units (c) and control (a); thermograms taken from the body of the CR-injector of the APDF A-04-011-00-00-03 with a serviceable control valve and atomizer (b)

\section{Results and discussion}

At the first stage, to verify the assumption about the dependence of operational parameters on temperature of the CR-injector units, the tests were carried out on a technically correct injector, the parameters of which are in the pre-launch zone according to the manufacturer's test plan (Figure 4). Changes in the cyclic flow at different temperatures of the body units are not significant and amounted to 204-206 $\mathrm{mm}^{3}$ / cycle, which corresponds to pre-launch values of $210 \pm 10 \mathrm{~mm}^{3} /$ cycle. The temperature differences between the control and spraying units are practically negligible. Figure 6 shows that the temperature increase of the CR-injector units is observed in the range of 1000-6000 injections (the first 6 minutes, not counting the warm-up mode) and then, due to heat and mass transfer, it stabilizes and evens out.

The second stage of the tests was to determine dependences of the operating parameters on the temperature of the CR-injector units under various technical conditions ("faulty control unit - correct atomization unit", "serviceable control unit - faulty atomization unit", "faulty control unitdefective atomization unit") (Figures 5-7). With a faulty control unit and a working atomizer, the temperature of the first unit is $10-20{ }^{\circ} \mathrm{C}$ higher during the first 4000 test cycles than the second (as in the case of a failure of both units) 


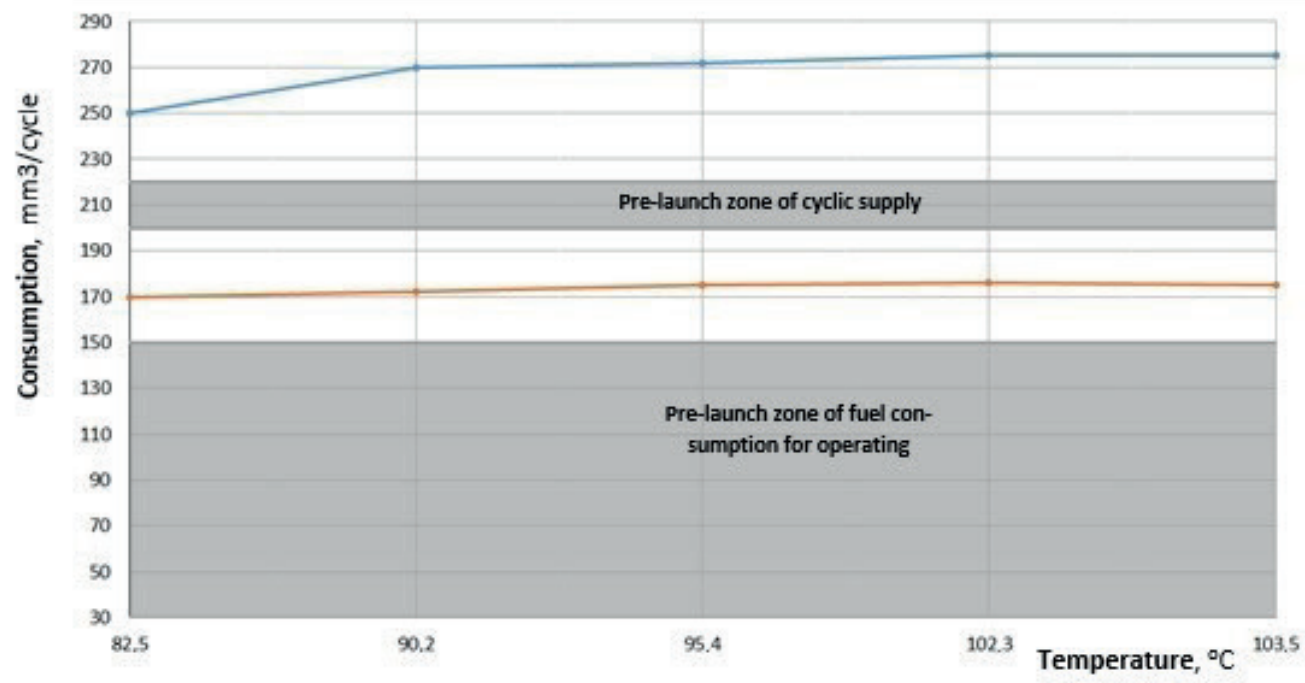

\section{actual cyclic supply, mm3 / cycle}

a) control unit
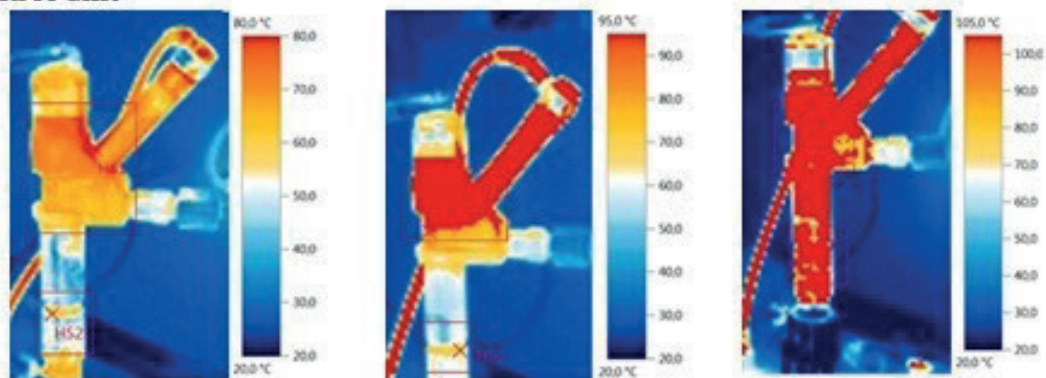

-- actual

fuel

consumption

for control, $\mathrm{mm} 3$ / cycle

b) thermograms taken from the body of the CR-injector

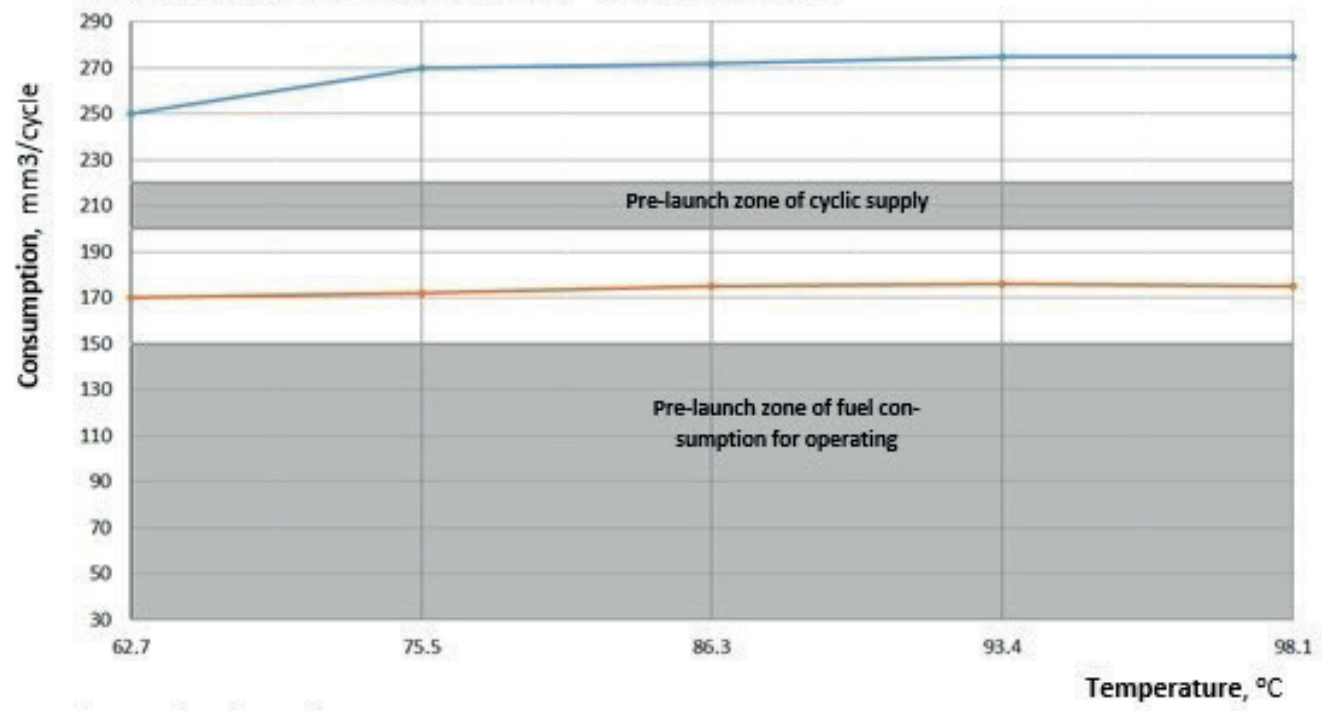

c) atomization unit

Figure 5 Dependences of the cyclic supply and fuel consumption for control on temperature of the housing of injection units (c) and control (a); thermograms taken from the body of the CR-injector of the APDF A - 04-011-00-00-03 (b) with a faulty control valve and serviceable sprayer

(Figures 5, 7) With the opposite faulty units - the situation changes to the opposite, but the temperature difference is already less significant $\approx 5^{\circ} \mathrm{C}$ (Figure 8 ).

The test results showed that the temperature of the units of the electronic injector can unambiguously characterize the technical condition of its units (scale: "working-faulty") and can be used to develop an in situ diagnostic method. Thus, a significant temperature difference between the control and spraying units characterizes the malfunction of the first.

The injector with faulty units can heat up to temperatures above $100{ }^{\circ} \mathrm{C}$, which is not safe when working on a car.

In existing technologies for diagnosing the CR-injectors, the technical condition of the product is evaluated only by measuring the fuel consumption for control and fuel delivery [1-2, 5, 7-8, 11-13, 17, 19-20], which characterizes 


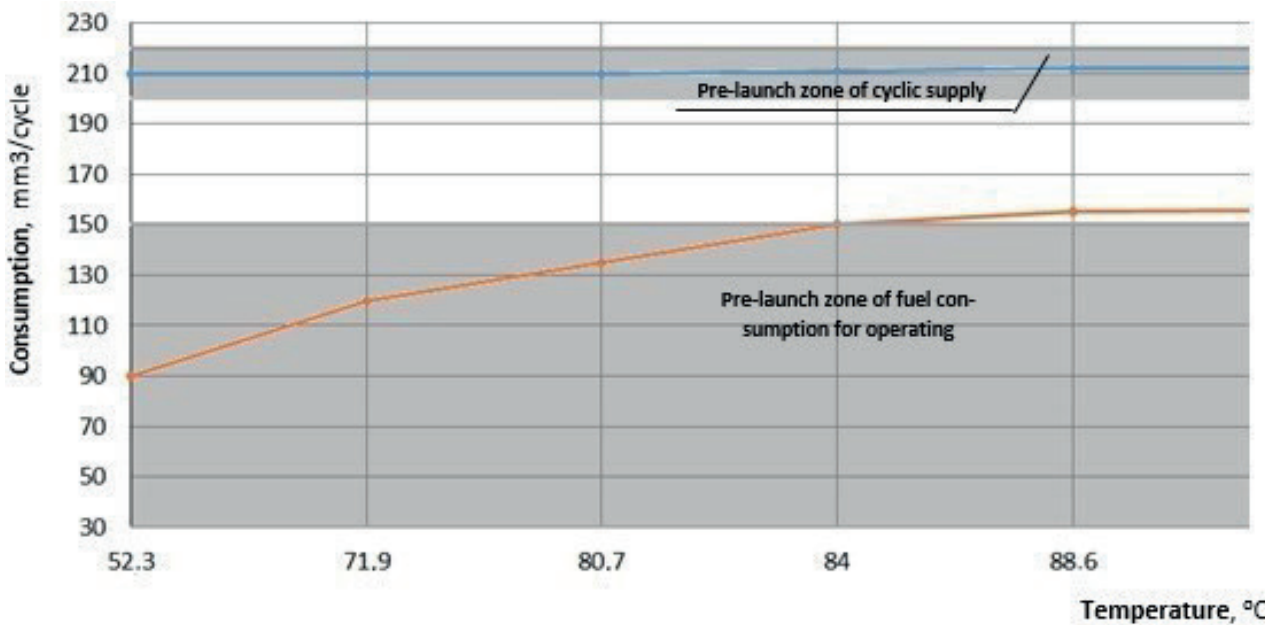

\section{- actual cyclic supply, mm3 / cycle}

a) control unit
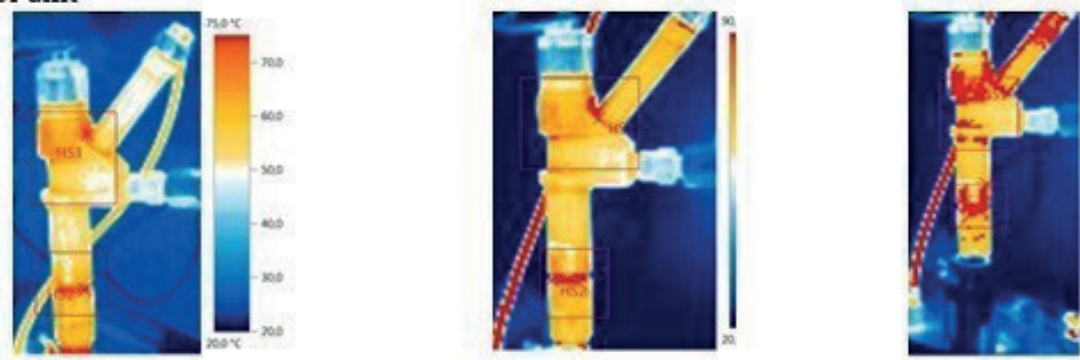

\section{-- actual fuel consumption for control, $\mathrm{mm} 3$ / cycle}

\section{b) thermograms taken from the body of the CR-injector}

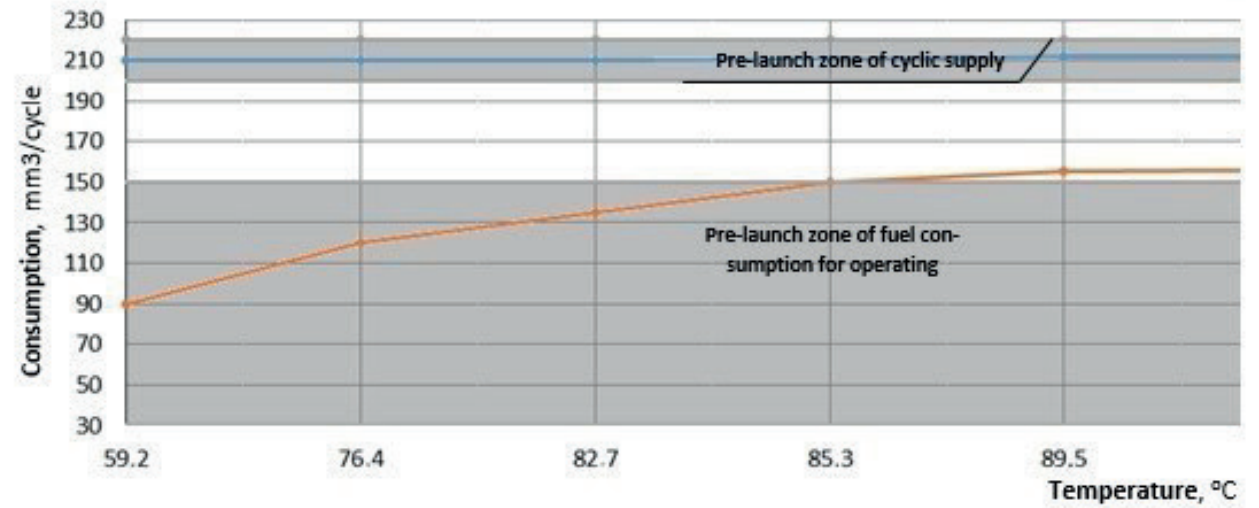

\section{c) atomization unit}

Figure 6 Dependences of the cyclic supply and fuel consumption for control on temperature of the housing of injection units (c) and control units (a); thermograms taken from the body of the CR-injector of the APDF A-04-011-00-00-03 with a serviceable control valve and a faulty atomizer (b)

the technical condition of the whole product. For example, in research [1] the authors suggest a hardening injectors valve unit to increase the life cycle of injectors. In article [4] researchers give a result of influences of fuel temperature on electromagnetic actuator operation. But they use standard Bosch's technologies to test the technical state of the whole unit. In publications $[8,12]$ various technologies and test benches are reported, but none of them uses temperature as a diagnostic parameter.

The results of the obtained experimental studies coincide with the works of Kolev [6] and Versteeg and Malalasekera [18], who established the pressure dependence on its temperature increase (at pressures of $200 \mathrm{MPa}$, the temperature increased to $120^{\circ} \mathrm{C}$ ), by methods of numerical simulation the solution of the Navier-Stokes equation on an unstructured grid for hydrodynamic processes of a singlephase fluid flow. It is due to fluid flows through small gaps at high speeds (the so-called viscous heating), which is typical for the fuel movement through "ball-to-seat", "seat-stem" pairs of the control valve and the "atomizer needle - its body" of the atomizer unit [18, 21-31]. Use of temperature of the housing units for atomizing and control as a diagnostic parameter makes it possible to determine the malfunction of a specific injector unit. 


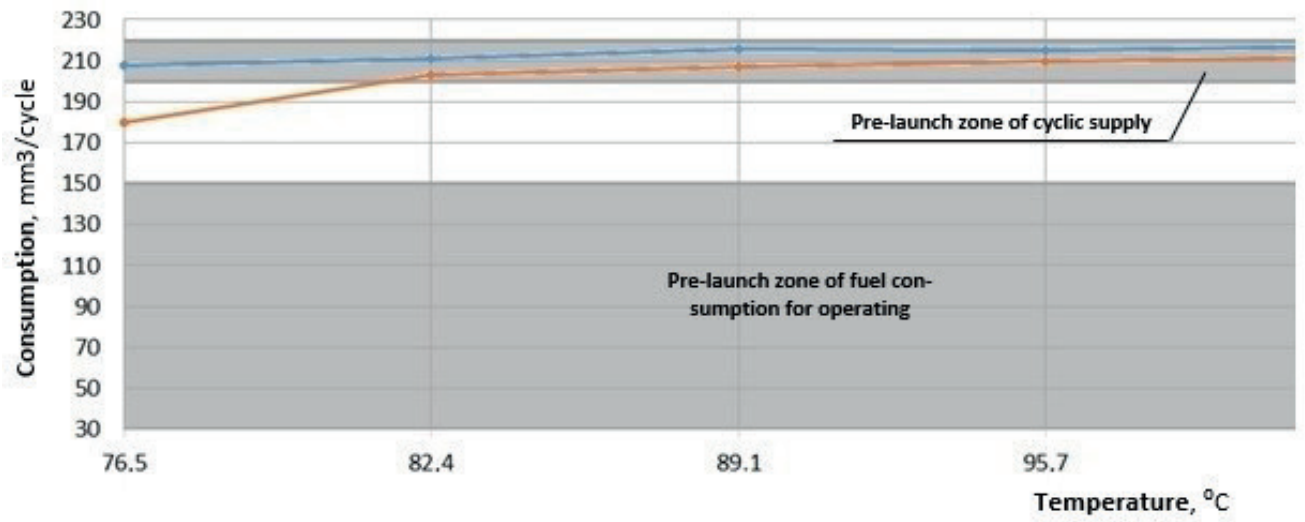

a) control unit
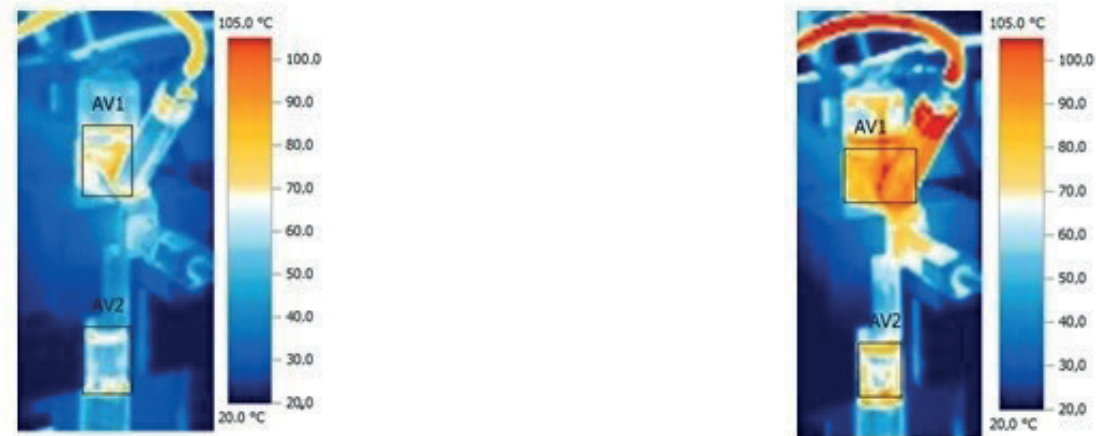

\section{-- actual cyclic supply, mm3 /cycle \\ -- actual fuel consumption for control, $\mathrm{mm} 3$ /cycle}

b) thermograms taken from the body of the CR-injector

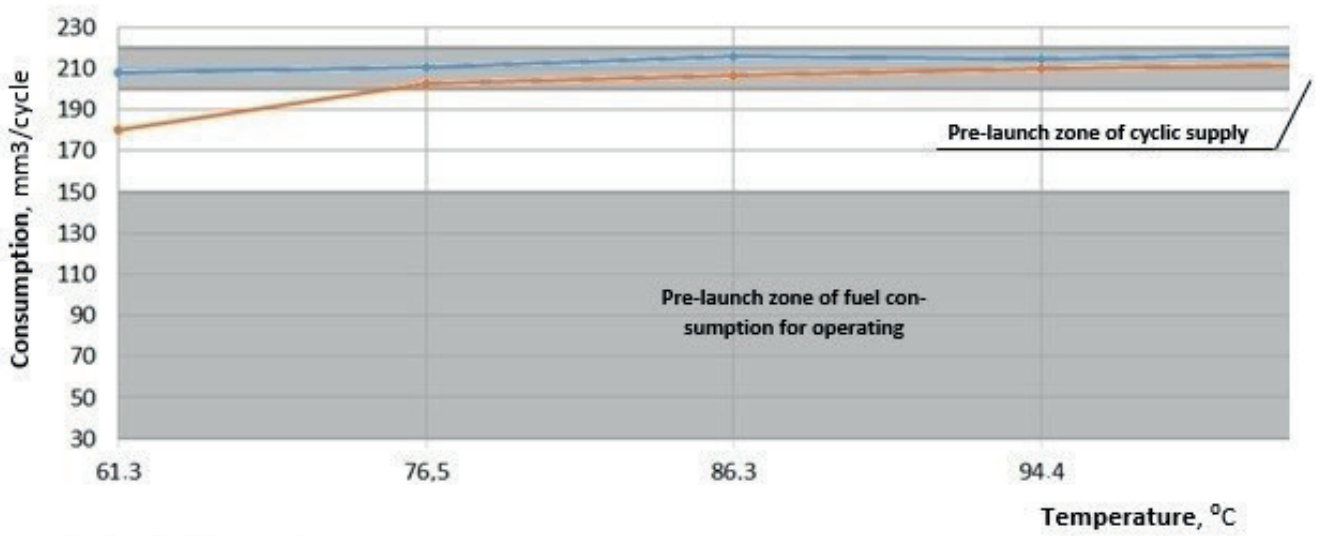

\section{c) atomization unit}

Figure 7 Dependences of the cyclic supply and fuel consumption for control on temperature of the housing of injection units (c) and control (a); thermograms taken from the body of the CR nozzle of the AZPI A-04-011-00-00-03 with a faulty control valve and sprayer $(b)$

\section{Conclusions}

In existing technologies, replacement of one broken CR unit does not guarantee the serviceability of another (repeated testing of the entire test cycle is required). Suggested technology is guarantees the more exact detection of the broken node(s) of CR injectors. So, the labor time is decreased from 30 to $15 \mathrm{~min} /$ person for each injector in the cases of the control and spraying units malfunction, either at the same time or one of them. The tests should be carried out at maximum torque mode, as the pressure at the inlet of the injector is maximum (according to the test plans of the FE manufacturing plants) and, as a result the hydrodynamic friction and heating of the units are the greatest. The temperature of the electronic injector units characterizes the technical condition of its units: a significant temperature difference between the control and atomizing units "indicates" the malfunction. It is necessary to "warm-up" the electronic injector by leakage to the "return", it is necessary to "warm it up" to $\approx 70{ }^{\circ} \mathrm{C}$ ("run" the injector at the pressure of the VL point (1600 bar) for the first 3000 cycles (but not later than 5000 cycles) and only then to search for a "worn-out" unit by measuring the temperature of its units. "Run" (injector heating) is due to the time required to heat the elements of the "worn-out" units by the hydrodynamic friction of the fuel through 
the element gaps. However, due to the heat-mass transfer effect after 5000 test cycles the temperature of the units is equalized.
The presented studies can serve as a basis for development of an in situ method for diagnosing the nodes of the CR-injectors by their temperature.

\section{References}

[1] GABITOV, I. I., SAIFUllin, R. N., FARHSHATOV, M. N., NEGOVORA, A. V., MUDARISOV, S. G., KHASANOV, E. R., VALIEV, A. R. Hardening of electrohydraulic injectors valve units of diesels at repair. Journal of Engineering and Applied Sciences [online]. 2018, 13(S8), p. 6478-6486. ISSN 1816-949x, eISSN 1818-7803. Available from: https://doi.org/10.36478/jeasci.2018.6478.6486

[2] ZHENG, L., XINGWANG, G. Factor analysis used in pulsed infrared thermographic NDT. Journal of Beijing University of Aeronautics and Astronautics [online]. 2010, 36(5), p. 622-626. ISSN 1001-5965.

[3] FERRARI, A., PIZZO, P. Fully predictive Common Rail fuel injection apparatus model and its application to global system dynamics analyses. International Journal of Engine Research [online]. 2017, 18(3), p. 273-290. ISSN 1468-0874, eISSN 2041-3149. Available from: https://doi.org/10.1177/1468087416653246

[4] SHAO, J., GREKHOV, L. Effect of fuel temperature on operation of high-speed electromagnetic actuator common rail injector. In: International conference on industrial engineering, applications and manufacturing ICIEAM 2019: proceedings. Institute of Electrical and Electronics Engineers Inc, 2019. eISBN 978-1-5386-8119-0, p. 1-6.

[5] THEVENIN, D., JANIGA, G. Optimization and computational fluid dynamics. Springer Science \& Business Media, 2008. ISBN 978-3-540-72152-9.

[6] KOLEV, N. I. Multiphase flow dynamics 1: fundamentals. Vol. 1. Springer Science \& Business Media, 2007. ISBN 978-3-540-69832-6.

[7] GREKHOV, L. V., GABITOV, I. I., NEGOVORA, A. V. Design, calculation and technical service of fuel-supplying diesel systems: training manual for students of universities enrolled in the specialties Internal Combustion Engines, Technology of service and repair of machinery in the agricultural sector, Agricultural mechanization: rivers. Legion-Avtodata, 2013. ISBN 978-5-88850-582-3.

[8] GABITOV, I. I., NEGOVORA, A. V., FEDORENKO, V. F. Intellectualization of the technical service of fuel-supplying diesel systems. Moscow: Rosinformagroteh, 2018. ISBN 978-5-7367-1398-1.

[9] BASHIROV, R. M. Automotive engines: design, the basics of theory and calculation. 2. ed. Ufa: Bashkir State Agrarian University, 2017. ISBN 978-5-7456-0391-4

[10] ZHAO, J., YUE, P., GREKHOV, L., WEI, K., MA, X. Temperature and frequency dependence of electrical iron effects on electromagnetic characteristics of high-speed solenoid valve for common rail injector. International Journal of Applied Electromagnetics and Mechanics [online]. 2019, 60(2), p. 173-185. ISSN 1383-5416, eISSN 1875-8800. Available from: https://doi.org/10.3233/JAE-180022

[11] GREKHOV, L., DENISOV, A., STARKOV, E. Diesel fuel injection by pressure up to $400 \mathrm{MPa}$. International Journal of Pharmacy and Technology. 2016, 8(4), p. 27208-27215. eISSN 0975-766X.

[12] MASING, M. V., TER-MKRTICHYAN, G. G., STARKOV, E. E. On certified tests of the new generation fuel equipment. Journal of Automobile Engineers. 2015, 3(92), p. 50-53. ISSN 2073-9133, eISSN 2073-9141.

[13] SALVADOR, F. J., PLAZAS, A. H., GIMENO, J., CARRERES, M. Complete modelling of a piezo actuator last-generation injector for diesel injection systems. International Journal of Engine Research [online]. 2014, 15(1), p. 3-19. ISSN 1468-0874, eISSN 2041-3149. Available from: https://doi.org/10.1177/1468087412455373

[14] State Standard 10578-95 Fuel diesel pumps. General specifications. Interstate standard diesel fuel pumps [online] [accessed 2020-03-05]. Available from: http://docs.cntd.ru/document/120023277.

[15] State Standard 10579-2017. Diesel nozzles. Technical requirements and test methods ISO 4008-1:1980. Road vehicles - Fuel injection pump testing - Part 1: Dynamic conditions [online] [accessed 2020-03-05]. Available from: https://standartgost.ru/g/\%D0\%93\%D0\%9E\%D0\%A1\%D0\%A2_10579-2017.

[16] ISO 8984-2:1993 Diesel engines - Testing of fuel injectors - Part 2: Test methods [online] [accessed 2020-03-05]. Available from: https://www.iso.org/ru/standard/16513.html.

[17] KAMALTDINOV, V. G., ROZHDESTVEnSkY, Y. V., LYSOV, I. O., POPOV, A. Y., NIKIFOROV, S. S. Experimental investigations of the effects of electric control impulse on injection characteristics of common rail type injector. Indian Journal of Science and Technology [online]. 2016, 9(42), p. 104-225. ISSN 0974-6846, eISSN 0974-5645. Available from: https://doi.org/10.17485/ijst/2016/v9i42/104225

[18] VERSTEEG, H. K., MALALASEKERA, W. An introduction to computational fluid dynamics: the finite volume method. Pearson Education, 2007. ISBN 978-0-13-127498.

[19] Presentation of Common Rail piezo injectors from Bosch - Robert Bosch GmbH, Automotive Aftermarket [online] [accessed 2020-03-07]. Available from: https://www.bosch-mobility-solutions.com/de/produkte-und-services/pkw-undleichte-nutzfahrzeuge/antriebssysteme/common-rail-system-piezo/. 
[20] YAN, F., WANG, J. Common rail injection system on-line parameter calibration for precise injection quantity control. In: 2010 American Control Conference: proceedings. IEEE, 2010. ISBN 978-1-4244-7427-1, p. 2248-2253.

[21] ZHAO, H., QUAN, S., DAI, M., POMRANING, E., SENECAL, P. K., XUE, Q., BATTISTONI, M., SOM, S. Validation of a three-dimensional internal nozzle flow model including automatic mesh generation and cavitation effects. In: Internal Combustion Engine Division Fall Technical Conference ASME 2013: proceedings. American Society of Mechanical Engineers Digital Collection, 2013. ISBN 978-0-7918-5610-9.

[22] ANDO, K., COLONIUS, T., BRENNEN, C. Numerical simulation of shock propagation in a polydisperse bubbly liquid. International Journal of Multiphase Flow [online]. 2011, 37(6), p. 596-608. ISSN 0301-9322. Available from: https://doi.org/10.1016/j.ijmultiphaseflow.2011.03.007

[23] FUSTER, D., COLONIUS, T. Modelling bubble clusters in compressible liquids. Journal of Fluid Mechanics [online]. 2011, 688, p. 352-389. ISSN 0022-1120. Available from: https://doi.org/10.1017/jfm.2011.380

[24] JAMALUDDIN, A., BALL, G., TURANGAN, C., LEIGHTON, T. The collapse of single bubbles and approximation of the far-field acoustic emissions for cavitation induced by shock wave lithotripsy. Journal of Fluid Mechanics [online]. 2011, 677, p. 305-341. ISSN 0022-1120. Available from: https://doi.org/10.1017/jfm.2011.85

[25] SAlVADOR, F. J., MARTINEZ-LOPEZ, J., ROMERO, J. V., ROSELlO, M. D. Computational study of the cavitation phenomenon and its interaction with the turbulence developed in diesel injector nozzles by Large Eddy Simulation (LES). Mathematical and Computer Modelling [online]. 2013, 57(7-8), p. 1656-1662. ISSN 0895-7177. Available from: https://doi.org/10.1016/j.mcm.2011.10.050

[26] SOTERIOU, C., ANDREWS, R., SMITH, M., TORRES, N., SANKHALPARA, S. The flow patterns and sprays of variable orifice nozzle geometries for diesel injection. SAE Transactions [online]. 2000, 109, p. 1007-1029. ISSN 0096-736X. Available from: https://doi.org/10.4271/2000-01-0943

[27] STADTKE, H. Gasdynamic aspects of two-phase flow: hyperbolicity, wave propagation phenomena and related numerical methods. John Wiley \& Sons, 2006. ISBN 978-3-527-405-78-7.

[28] STROTOS, G., KOUKOUVINIS, P., THEODORAKAKOS, A., GAVAISES, M. Quantification of friction-induced heating in tapered diesel orifices. In: Rouen 2014 International Conference and Exhibition: proceedings. France: SIA Powertrain, 2014.

[29] STRotos, G., KOUKOUVINIS, P., ThEODORAKAKOS, A., GAVAISES, M., WANG, L., LI, J., MCDAVID, R. M. Fuel heating in high pressure diesel nozzles. In: International Conference Thiesel 2014: proceedings. Valencia, Spain: Universitat Politecnica de Valencis, 2014.

[30] THEODORAKAKOS, A., MiTROGLOU, N., STROTOS, G., ATKIN, C., GAVAISES, M. Friction induced heating in nozzle hole micro-channels under extreme fuel pressurisation. Fuel [online]. 2014, 123, p. 143-150. ISSN 0016-2361. Available from: https://doi.org/10.1016/j.fuel.2014.01.050

[31] STROTOS, G., KOUKOUVINIS, P., THEODORAKAKOS, A., GAVAISES, M., BERGELES, G. Transient heating effects in high pressure diesel injector nozzles. International Journal of Heat and Fluid Flow [online]. 2015, 51, p. 257-267. ISSN 0142-727X. Available from: https://doi.org/10.1016/j.ijheatfluidflow.2014.10.010 